\title{
The Implementation of Integrated One-Stop Service at Licensing Service Agency in Order to Improve Licensing Service to Society (Case Study On Business License Service At Investment And Integrated Licensing Service Agency (IILSA) Of Pasuruan City)
}

\author{
Priyani Dini Pramita ${ }^{1}$, Siti Rochmah ${ }^{1.2}$, Ratih Nur Pratiwi ${ }^{1.2}$ \\ ${ }^{1}$ Master of Public Administration, Faculty of Administrative Science, Brawijaya University, Malang \\ ${ }^{2}$ Faculty of Administrative Science, Brawijaya University, Malang
}

\begin{abstract}
This study discusses about the implementation of integrated one-stop licensing services related to service of SIUP, conducted by the Investment and Integrated Licensing Service Agency (IILSA) in Pasuruan City. In general there are any issues related to License for business activities, namely: the complicated procedures, high costs and legal uncertainty. To overcome this problem the government issued Permendagri number 24 of 2006 about Guidelines for the Implementation of One Stop Services. The focus of this study discusses the implementation of an integrated one-stop service, based on the rules associated with seeing some of the following elements: (1) executing actor (2) communication (3) resources (4) bureaucratic structure (5) the target group. This research used descriptive method with qualitative research approach. Activity of data analysis in this study consisted of data reduction, display and verification of data. The result of this research can be said that the implementation is done by IILSA of Pasuruan city has been good although there are a few things that need to be improved related to the internet connection is still an obstacle in the implementation of the operational in the delivery service for SIUP and also the lack of facilities and infrastructure available.
\end{abstract}

Keywords: Improve Service, IILSA of Pasuruan City, Licensing Service, SIUP (Business License), The Implementation

\section{INTRODUCTION}

The development local autonomy entered a new phase after the passage of law Number 32 year 2004 concerning regional Governments in lieu of law Number 22 year 1999. While local governments own affairs includes matters relating to basic services such as education, health care, the fulfillment of the necessities of life and infrastructure, and matters that are closely related to the development of the potential of regional distinctiveness and flagship [1].

Services became a very important thing to concern the traceability with the introduction of its law Number 32 year 2004 about local government. The enactment of the regulation will make consequence in the interaction between local officials and the public is becoming more intense. And then, with increasingly strong demands for democratization and recognition of human rights would give appear to the demands

\footnotetext{
Corresponding Address:

Priyani Dini Pramita

Email : priyanidini25@gmail.com

Address : Dusun Kampung Baru RT.01/RW.03, Desa Bandaran, Kecamatan Winongan, Kabupaten Pasuruan, 67182
}

of quality management. In line with the times, the demands to improve service quality will increase. Moreover, associated with the global context that characterized by a high level of competition, government agencies (both in the Centre and in the regions) is claimed to be able to improve the quality of service in order to be able to compete.

Basically every human being needs a service. Licensing is one of the important aspects in the public service, as well as the license that are associated with business activities. The licensing process, in particular the business licensing, will directly affect the desire and the decision to aspiring entrepreneurs and investors to invest the capital. In the other way, if the licensing process is inefficient, convoluted, and not transparent either in terms of time, cost, and the procedure will have an impact on decreasing the desire of society to take care of licensing. This of course would have an impact on the availability of employment and other employment issues that will ultimately have an impact also on the local income/PAD. Based on the report of the World Economic Forum (WEF) on the present, global competitive ability in 2006-2007, indicating that Indonesia still ranks 50th out of 125 countries in terms of ease of 
licensing (www.transparansi.or.id), it does have a meaning that Indonesia in Issues of Licensing can still be said to be difficult or not easy.

In globalization era as it is now, the business sector was increasing rapidly. No wonder when we see standing businesses from small business, medium and large. For established businesses, businessmen must have a business license to trade or often called SIUP. As a service provider licensing Agencies, institution of integrated Licensing are required to have a good quality of service in the delivery service. The quality of a government agency can be seen and measured from public service standard. Standard public services include: servicing Procedures, cost of service, time service, requirements, infrastructure, the competence of public servant and product of services.

SIUP is the legality of a business that become basis for businessmen to conduct the business activities. SIUP has an important role and as one of the prerequisites in the entire sector trade activities around in local, national, and international. The quality of public services in the sector of licensing businesses play an important role in attracting investors to invest capital in an area. Licensing service quality can also be identified from the regulation of local government in supporting and providing the legitimacy of institutions licensing in the area to provide services more efficiently and effectively. Improving the licensing business in the era of decentralization not only requires the licensing business continuity between the Central government and the regions, but also requires support from institutional, personnel, technology, and financial.

In response all forms of weakness in the service of licensing conducted by local governments so the Ministry of the Interior issued a Regulation in the form of Permendagri Number 24 year 2006 about the guidelines for the Implementation of Integrated One Stop Service. It has become of fresh issue to the actors in business sector to take care of licensing easier as it is implemented in one place especially for businessmen. So did that happen in the Pasuruan city, since the enactment of Permendagri No. 24 in 2006 and based on the Number Permendagri Number 20 year 2008 about the guidelines of the Organization and the work of the integrated Licensing Service Unit in the area demanding of investment and Integrated Licensing service Agency (IILSA) as the agency authorized to perform licensing services to implement integrated One stop service in the discharge of his duty to provide service to the community. Implementation of licensing services in the Pasuruan City, Investment and Integrated Licensing Service Agency (IILSA) also is based on Regulation of Pasuruan Mayor Number 8 year 2010.

But although it has been a few years since the enactment of Permendagri No. 24 of 2006 integrated service system, the one stop service that has run by the Investment and Integrated Licensing Service Agency (IILSA) the Pasuruan city may not necessarily be giving significant changes on the Pasuruan city community response in taking care of its trade business license. Implementing integrated one stop service by IILSA of Pasuruan city as strategy of improving service to the public is not simply making Pasuruan society flocked take care of Licensing for their trading business. It is known from the data obtained from the Department of cooperatives, industry and trade Pasuruan City reported in 2011 there is existing trading business 2.498. While the report from Investment and Integrates Lisensing Service Agency Pasuruan city in 2012 just issued a license for the trading business of around 255 trade business License.

The purposes of this research were to describe and analyze the implementation of One Stop Service at Investment and Integrated Licensing Service Agency (IILSA) In Order To Improve Licensing Service To Society in giving Business License (SIUP) at Investment and Integrated Licensing Service Agency (IILSA) of Pasuruan City. The second purpose is describe and analyze the factors that supporting or prohibiting the Implementation of One Stop Service at Investment and Integrated Licensing Service Agency (IILSA) of Pasuruan City.

From the background research described, the author interested to know and investigated how the implementation of integrated one stop service based on Regulation of Home Affair Ministry Number 24 year 2006. Thus, the authors was conduct research with the title "The Implementation of One Stop Service at Investment and Integrated Licensing Service Agency (IILSA) In Order to Improve Licensing Service to Society" (Case Study on Business License Service at Investment and Integrated Licensing Service Agency (IILSA) of Pasuruan City). 
Based on the background described above, the detailed formulation of the problem statement are, as follows:

1. How the implementation of one stop service at Investment and Integrated Licensing Service Agency (IILSA) in order to improve licensing service to society?

2. What are the factors that supporting and prohibiting the implementation of One Stop Service at Investment and Integrated Licensing Service Agency (IILSA) in order to improve licensing service to society?

\section{RESEARCH METHOD}

This research used descriptive research method with qualitative approach. Research site in the Investment and Integrated Licensing Service Agency (IILSA) of Pasuruan City.

\section{Data Collection Techniques}

The technique of data collection is a method that can be used by researchers to collect the necessary data in the study. These following data collection techniques in the study, are:

collection techniques in the study, are:

1. Observation

Observation is one of the data collection techniques used by researchers to conduct systematic observation and recording of the studied object. This is done in order to obtain directly the implementation of integrated one stop service in order to improve licensing service to society undertaken by IILSA of Pasuruan City.

2. Interview

Interviews are activities to look for material (information, opinion) through a verbal debriefing with people who are considered to have knowledge of the studied object. Interview technique is conducted to reveal the background, motives that are around at the observed problems. Interviews were conducted because the information or opinions in any other way can not or difficult to be obtain. Interviews in this study are done by the researcher did with the Chief of IILSA of Pasuruan City, Head of Evaluation and Planning, Head of Service, Head of Information and Complaints, and staff / employee other at IILSA of Pasuruan City which is considered to assist in the acquisition of data that researchers need. All of this involved in to primary data.

3. Documentation

To complement the data obtained by observation and interview, the documentation is also important in this research. Documentation is data collection techniques by recording or copying the data in the document of research sites, and then examining the document in accordance with the problems examined. In this study, the documents as the secondary data that support the primary data are as follows:

a. The archives are owned by IILSA of Pasuruan city related to research activities that researcher was done.

b. Pasuruan in Figures (Central Bureau of Statistics).

c. Data from the Internet (Web site owned by IILSA of Pasuruan)

d. Laws and regulations which the law:

1. Law Number 32 Year 2004 about Local Government.

2. Law Number 25 year 2009 about Public Service.

3. Government Regulation Number 65 Year 2005 about Guidelines for the Preparation and Implementation of Minimum Service Standards.

4. Regulation of the Minister of Home Affairs Number 24 year 2006 about Guidelines for Implementation of One Stop Integrated Services.

5. Regulation of the Minister of Home Affairs Number 20 Year 2008 about Guidelines for Organization and Work Integrated Licensing Services Unit in the Region.

6. Pasuruan Regional Regulation Number 10 Year 2008 about Regional Technical Institute

7. Major Regulation Pasuruan Number 8 year 2010 concerning Delegation of Authority In Granting Licensing In Pasuruan

8. KepmenPan Number 63 Year 2003 about Guidance Services

\section{Data Analysis Techniques}

The reason for using qualitative data analysis was selected because of the kind of research is a descriptive study that attempted to describe it and explain the phenomenon. In an effort to shed some light on this phenomenon, was be more easily to understand if the data are in the form of words or phrases (qualitative data) rather than numeric data. Because there are tangible qualitative data it was be faster if the process using qualitative data analysis. The activity in the data analysis carried out in an interactive and takes place continuously until completion. Interactive models in the analysis of the data shown in the following figure: [2] 


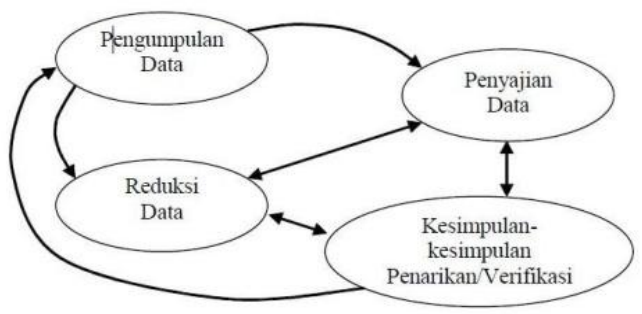

Figure1. Interactive Model Of Data Analysis [2]

The data analysis activities was be performed by the following process: (1) Data Reduction, the selection process or reducing the data that is meaningful summarized, choose basic things, focus on the important things learned from IILSA of Pasuruan City. The data are associated with the implementation of one stop service undertaken by IILSA of Pasuruan City in order to improve public services and its influence factors. (2) Present of Data (Data Display), the presentation of data can be done in the form of a short description, charts and or relationships category, in the sense of organizing the data into a set of information that gives a conclusion. (3) Verification, this activity is to conclude the field notes and presented as conclusions in the form of the phenomena occurring in IILSA of Pasuruan City related to service quality improvement in implementing integrated licensing service. Conclusions can be regarded as a credible conclusion because of the conclusions in this study based on the phenomenon that actually occurs and in accordance with what has been delivered by the speaker.

\section{RESULT AND DISCUSSION}

The Implementation of Integrated One Stop Service Undertaken by Investment and Integrated Licensing Service Agency (IILSA) of pasuruan City

\section{a) Actors and Institution of Policy Implementation}

Actually, before and after the implementation of integrated one-stop service, of course there are different actors and agencies involved in the licensing process. The regulation regarding the implementation of one stop service can be seen in the difference mechanisms and processes, service providers and agency. This is because the promulgation of regulation about integrated one-stop service intended to provide convenience to the community in the licensing process. The differences mechanism of licensing service in Business license can be seen in the picture as follow:

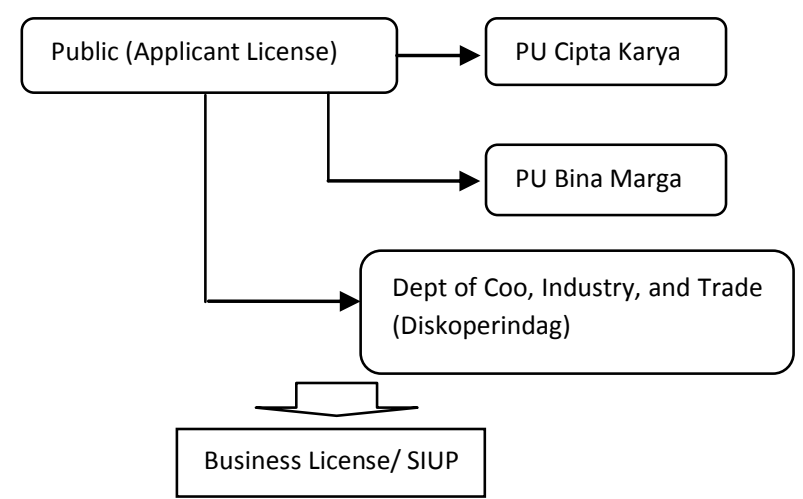

Figure 2. Mechanism license service of Business License (SIUP) before OSS

Source: Data processed by researcher (2013)

And then, after implementation of Permendagri Number 24 year 2006, the mechanism of license service for Business license become more simple and quickly:

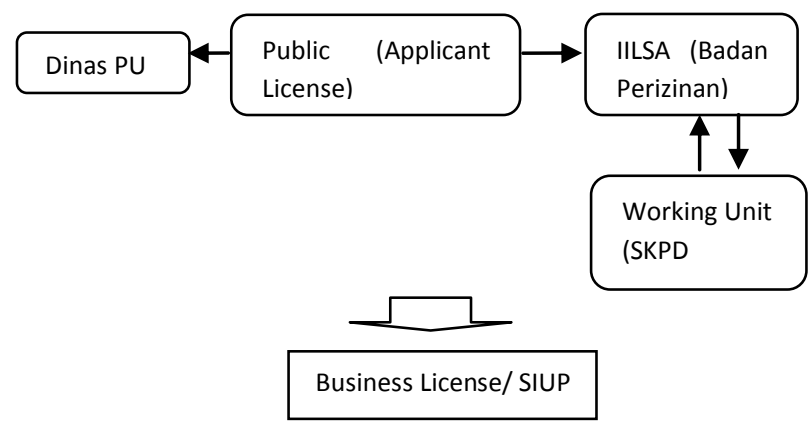

Figure 3. Mechanism license service of Business License (SIUP) after OSS

Source: Data processed by researcher (2013)

From the both figure. 4 and figure. 5 about mechanism licensing service before and after implement integrated one stop service we can see that many proses can be cut or more simple when one stop service implemented in IILSA of Pasuruan city.

Differences actors/official that involved in processing of license as follow:

1. Before implement integrated one stop service, the applicant of service must come to several office to get a SIUP. There must come to Cipta Karya (Public work official) and then going to Bina Marga (public works official) to arrange the building that used in trading business. In the last office that must be came namely Dept of Cooperation, Industry, and trading to get a SIUP. There are needed a long 
process, long time and more expensive cost to get a Business License/ SIUP.

2. After implemented integrated one stop service, the applicant just come to IILSA only until the Business license acc from head of IILSA and issued, although before that applicant of service need a recommendation from Public Work office (Dinas Pekerjaan Umum) to arrange the calculation of construction and other requirement.

Especially in service of giving Licensing Service/SIUP, if viewed on the procedures and mechanisms of service delivery in Figure 6, it can be known to be actor-the actors involved in the implementation of integrated permissions in pasuruan city in the services of SIUP, as a realization of Permendagri Number 242006 that implemented by IILSA of Pasuruan city its as follows:

1. Head of agency: as the person responsible for the passage of all activities undertaken by IILSA of Pasuruan and also as a person entitled to give consent to the agreement the issue the Business License or SIUP.

2. Head of Division of Investment: the duty to correct the validity and completeness from the license applicant's file. From the research that has been conducted by researchers, the work is handed over to the Head of Sub Division Control and Supervision of Investment.

3. Customer Service / Officers in charge of counter service for receiving files from the Applicant.

And then about establishment of IILSA of Pasuruan city as a agency authorized to give a license, in Pasuruan City establishment of IILSA in 2008 and started the operational since 2009. The establishment of IILSA have a legal basic from several rule there are Permendagri number 24/2006, permendagri number 41/2007, permendagri number 57/2007 and then Regional rule there are Regulation of mayor number 08/2010 and number 06/2013.

\section{b) Communication}

The licensing procedure/flow or curbing SIUP can be outlined as follows, beginning with the plot:

1. Applicant comes with the completeness of the file and fill in the form application for license submitted by customer service in accordance with the applicable requirements.

2. Customer Service who served as a liaison between the applicant and the IILSA check the completeness of the documents and the applicant sign in file validity. If a file that must be completed complies with all the provisions that must be completed as the completeness of requirements, it will be given a registration number which serves as an identity during the publishing process SIUP implemented. If there is a lack of data or incomplete data can be said, it will be returned to the applicant to come. So the process management/ publishing of SIUP can continue to be processed.

3. Customer service which acts to perform checking of completeness of requirements will continue to submit the document to the licensing of certain Fields, if the document is valid then the staff officers of the licensing of certain fields will input the data and review date and define the field. Before doing a review of the field, staff first make certain tasks as well as invitations to several related institutions to participate in the review of the field. In the implementation of the review of the field also included a letter which contains documents of the BAP and the condition of the field, designation, levy, levy and collection. After all the processes running, just wait for the making and signature in SK.

4. relevant agencies namely Department of PU, for trade and industry, the Environmental Agency, Satpol PP irrigation and receive an invitation to review the field along certain areas of licensing employees staff in the management of the issuance of the permit.

5. The Secretary is in charge of receiving a deposit levy from the applicant sent via Bank Jatim in IILSA of Pasuruan city and do the bookkeeping as well as give SK and receive the file of the applicant to be archived.

6. The head of the Agency is authorized to sign the letter of assignment and coordination of technical meeting invitations to related to related services, as well as sign a draft DECREE certain Permissions from the fields.

7. The DECREE which has been completed and signed by the head of the Agency, will be returned to the customer service to be used as inputs are ultimately left to the applicant.

From the procedures and mechanisms above, constitute a public service Standard guidelines which became priorities in improving the quality of service through the implementation of integrated service of one door can be fulfilled. So more or less able to meet the 
expectations of society are feeling the presence of Pasuruan value of services provided by the IILSA of Pasuruan city. The fulfillment of the resolution procedure permits trade/SIUP proved more simple, because already implement integrated service of one door. The community does not need to switch places/offices maintain its trading permission, just go to the Licensing Agency or simply alone. This is contrary to the conditions of service before using the service, where one door integrated service is considered too convoluted so that it became one of the factors people are reluctant to apply for permission for its trading business.

\section{c). Resources}

\section{- Staff}

IILSA of Pasuruan city have employees as many as 39 people with the highest education levels to the lowest. Here is the breakdown of the number of employees at the BPMPPT level of education based on the town of pasuruan:

Table.1 The Level of Education of Employee in IILSA Of Pasuruan City

\begin{tabular}{ccc}
\hline No. & $\begin{array}{c}\text { Levels of } \\
\text { Education }\end{array}$ & $\begin{array}{c}\text { Amount of } \\
\text { Employee }\end{array}$ \\
\hline 1. & SLTA & 14 \\
2. & Diploma-3 & 5 \\
3. & Strata-1 & 11 \\
4. & Strata-2 & 9 \\
& Jumlah & 39 \\
\hline
\end{tabular}

Sources : Archives of IILSA of Pasuruan City

The implementation of one stop service integrated that was held by IILSA can take place properly in the presence of qualified human resources. By making education and training, organizational goals can be achieved. The existence of such training and education be hope IILSA can improve the ability of the apparatus, particularly in licensing services to the community. In addition to the existence of training expected the apparatus can undergo a change in his activities because of their increased knowledge and insights as well as having a framework in the future.

\section{- Infrastructure}

The main means of public services and infrastructure that exist in IILSA of Pasuruan city consists of:

1. Office Building Integrated is addressed at Jl.Pahlawan No. 26 B Pasuruan. As for the building is divided into:

a. Applicant waiting area (community) b. Licensing Counters (Counter Information and Complaints)

c. Room of Head agency

d. Room of Secretary

e. Room of Secretariat

f. Room of Dept of Service

g. Room of Dept of Information and complaints

h. Room of Dept Development

i. Room of Dept of Investment

j. meeting rooms

k. the archives

I. mushollah

m. toilet

n. parking area

Tabel.2. The Employee as a Partisipant in Training in the IILSA

\begin{tabular}{|c|c|c|c|c|}
\hline No & Nama & $\begin{array}{l}\text { Jabatan/ } \\
\text { Golongan }\end{array}$ & $\begin{array}{c}\text { Tahun } \\
\text { Pelatihan }\end{array}$ & $\begin{array}{l}\text { Jenis } \\
\text { Diklat }\end{array}$ \\
\hline \multirow{2}{*}{1.} & Drs. & Pembina & 2010 & Diklat \\
\hline & Hasanudin & Tk.I (IV/b) & $\& 2011$ & PTSP \\
\hline 2. & $\begin{array}{c}\text { Drs. } \\
\text { Mohammad } \\
\text { Arifin, MM }\end{array}$ & $\begin{array}{l}\text { Pembina } \\
\text { (IV/a) }\end{array}$ & 2010 & $\begin{array}{l}\text { Diklat } \\
\text { PTSP }\end{array}$ \\
\hline 3. & $\begin{array}{c}\text { Hj. Siti } \\
\text { Rochana, ST, } \\
\text { M.Si }\end{array}$ & $\begin{array}{l}\text { Pembina } \\
\text { (IV/a) }\end{array}$ & $\begin{array}{c}2010 \& 201 \\
1\end{array}$ & $\begin{array}{l}\text { Dlklat } \\
\text { PTSP }\end{array}$ \\
\hline 4. & $\begin{array}{c}\text { Indra } \\
\text { Gunawan, ST }\end{array}$ & $\begin{array}{c}\text { Penata } \\
\text { (III/c) }\end{array}$ & $\begin{array}{c}2010 \& 201 \\
1\end{array}$ & $\begin{array}{l}\text { Diklat } \\
\text { PTSP }\end{array}$ \\
\hline 5. & Fajar Syodiq & $\begin{array}{l}\text { Pengatur } \\
\text { (II/c) }\end{array}$ & 2010 & $\begin{array}{l}\text { Diklat } \\
\text { PTSP }\end{array}$ \\
\hline 6. & $\begin{array}{l}\text { Eko Sulistyo } \\
\text { Wibowo }\end{array}$ & $\begin{array}{l}\text { Pengatur } \\
\text { Muda Tk.I } \\
\text { (II/b) }\end{array}$ & 2010 & $\begin{array}{l}\text { Diklat } \\
\text { SPIPISE }\end{array}$ \\
\hline 7 & Fajar Syodiq & $\begin{array}{l}\text { Pengatur } \\
\text { (II/c) }\end{array}$ & 2011 & $\begin{array}{l}\text { DIklat } \\
\text { SPIPISE }\end{array}$ \\
\hline 8 & $\begin{array}{c}\text { Eko Sulistyo } \\
\text { Wibowo }\end{array}$ & $\begin{array}{l}\text { Pengatur } \\
\text { Muda Tk.I } \\
\text { (II/b) }\end{array}$ & 2011 & $\begin{array}{l}\text { Diklat } \\
\text { SPIPISE }\end{array}$ \\
\hline
\end{tabular}

Source: data processed from interview by researcher (2013)

2. The Major of Office Equipment

The main office equipment that supports the process of licensing services in IILSA of pasuruan City are as follows:
a. Car Office (by 1)
b. Car Operations (1)
c. Motorcycles (5)
d. Computers and laptops (40)
e. $\operatorname{LCD}(3)$
f. Printer (25)
g. Telephone/ Facsimile (2)

\section{d. Bureaucracy Structure of IILSA of Pasuruan City}

On the Figure 2 on the bureaucratic structure in IILSA shows that the composition of 
the organization can be said already flexible. This organizational structure based on local regulations 26 Year Pasuruan in 2011 about the Organization and The Labor Inspectorate, the regional development planning board and the Technical Institute of The city of Pasuruan. All of the problems associated with the licensing issues can already covered by the existing structure of the organization is run by IILSA of Pasuruan. The organizational structure is composed of the head of the Agency then below there is a functional Office and group Secretary.

Where the Secretary of the Navy with 3 Sub Division namely sub-division of planning and evaluation, Public Sub sections and Sub sections as well as financial Staffing. Then the head of the Agency Directly Oversees the Field 4 field service, Field Information and complaint, the field Data and the development and investment Fields, each of which has a specific function and basic tasks in accordance with those powers.

\section{e. Target Group of Implementation of Integrated One Stop Service}

In the process of implementing a policy then there is one element that is important to concern they are the target group. The Target group is a group of people or organizations within the community that will receive the goods or services that will be affected his behaviour by policy. Based on the research that has been done with regard to the target group in the context of the implementation of the policies that the characteristic that belongs to the target group such as: magnitude group, gender, level of education, experience, age and socio-economic conditions affecting the effectiveness of implementation. Public policy starting from the existence of a claim or the support of a group of people in an effort to overcome a public problem, therefore they were included into the important elements of a public policy.

The Government in fact is the servant of the communities, the Government has embodied for providing service to the community. Community as the party that obtained the Ministry certainly crave good service and satisfying. So with the promulgation of permendagri No. 24 year 2006 about the guidelines of integrated one stop service of, then that becomes a target group in this policy was the community as recipients of services. That is a people who need legalization of business license from the Government in for running the trading business.
With a variety of activities, businesses, as well as programs that do IILSA of Pasuruan City Pasuruan in order to improve the quality of service, then it can be achieved by increasing the number of licenses by the community. With the increasing number of services performed by community permits this to be an indicator that increased public awareness with all efforts made by IILSA of Pasuruan City. It can be seen from the comparison table. 7, table. 8 and table. 9 the number / license number increases each year and investment in the region is increasing.

Factors that Affecting the Implementation of Integrated One Stop Service Undertaken by Investment and Integrated Licensing Service Agency (IILSA) of pasuruan City

a. Supporting Factor

1. Internal Factor

a. The existence of directives / strong commitment from leadership.

Not all jobs are charged to employees / subordinates can understand fully well, as well as with the leadership did not control all the details about the work of his subordinates. Therefore, it needs good cooperation between leaders and subordinates. In this case the head of the IILSA has full authority to provide guidance on the implementation of one stop service run. Briefing the good and high commitment of the leadership to provide direction and motivation to its employees greatly affect the success of programs that run in the context of the success of the one stop service.

b. The existence of adequate and qualified human resources

Other supporting factors in influencing the internal office integrated one-stop service delivery is the human resources / personnel are qualified and reliable. This is of course very much related to the first factor of the commitment of the leadership. When the head of the agency to give direction it is of course intended that the employee is able to work well and provide quality service. So the role of leadership and employee in this case can not be separated. Good cooperation between these two very influential on the success implementation of one stop service to service of SIUP. Human resources/personnel's quality affects the quality of service.

c. Systems and procedures are clear

One of the factors supporting the implementation of the internal one stop service to permit the service SIUP is the system and 
procedures that remain and the availability of licensing regulations. In support of IILSA performance in holding one stop service to permit the service SIUP presence service systems and procedures that will facilitate the permanent employees in providing services to the public SIUP. It is very important to avoid confusion in carrying out their respective duties.

\section{External Factor}

In addition to the internal factors, there are also external factors that affect the supporting integrated one-stop service delivery.

Then the demands of the center of the local revenue on a specific target it also encourages the implementation of integrated one-stop service. The existence of these targets make BPMPPT must continue to improve its service. In addition to the demands of the center, the demands of the public about better services encourage IILSA of Pasuruan city to continue to improve its services in order to create an integrated service delivery quality permits .

\section{b. Inhibiting Factor}

\section{Internal factor}

\section{a. Budget or funding}

Budget is a thing that relate to money or costs, among others, relating to income, amount of money and financial management in accordance with the objectives and regulations. Factors finance / budget or financing is very important in any activity or program of government work, because almost no government activities that do not require a fee. The greater the money or budget available, the more likelihood that the program can be implemented.

\section{b . Internet Network}

As we already know that at the time are now using the internet facility. Likewise also with IILSA of Pasuruan, that in order to facilitate coordination with the IILSA internet service is indispensable. The online system also permits to carry out transactions using internet facilities. It is therefore that the internet facility available is very influential on the implementation of the integrated services. If the internet connection interruption occurs, the online system will be offline and hinder the work of service providers. Given all processes started online.

\section{c. Lack of facilities and infrastructure}

Other constraints that affect the implementation of an integrated licensing services are limited facilities and infrastructure. The amount of authority possessed IILSA in managing the affairs of licensing services has consequences should the availability of equipment or facilities and adequate infrastructure. Based on interviews conducted by the researchers that IILSA of Pasuruan city still have shortcomings such as vehicles for operational and other equipment.

2. External factor

In addition to the internal inhibiting factors, the obstacles to the implementation of integrated services in IILSA of Pasuruan city external factors which could come from knowledge and technology. Lack of understanding about science and technology apparatus, can be a barrier to the provision of services to a unified licensing services SIUP permission. In connection with the rapid technological advances and increasingly sophisticated, leading to a renewed demand for facilities for the development organization.

From the all explanation above about one stop service in Pasuruan City, this research might give contibute to public administrastion, there are:

1. This research can be a material tools of critical thinking in learning bureaucracy in the system of government in Indonesia, particularly regarding the arrangement of local governments in providing licensing services in local area.

2. As a tools to add knowledge and information about the public service especially in the affair of public services and administrative services as a means of applying the theory in public administration.

3. To develop and provide additional reference and feedback to the community and certain parties related to the implementation of public services particularly in the problem of licensing.

This study has a position for comparison with other studies related to the implementation of the licensing issues one stop service. This study describes the Pasuruan city government, there are Agency of investment and Integrated Licensing Services as the executive one stop service, it can be concluded that there is many link with other agencies in making licensing that is not yet fully integrated. But, in general, IILSA already doing service properly resulting in increased local revenue associated with licensing. thus this research into a comparison to research conducted by others that describe the implementation of one-stop service in other areas. 


\section{CONCLUSION AND RECOMMENDATION Conclusion}

1. The Investment and Integrated Licensing service Agency (IILSA) of Pasuruan City can implement one stop service related to Business License with seeing several element, as follow:

a. Actors who impelement a one stop service namely: Head of IILSA as a responsible one to issuance a License, some employees: head of division of investment as the examiner completeness and validity of the data files from applicant, file clerk at the counter service and technical team review the field from IILSA and related local government offices are public works (PU Cipta Karya). The Establishment of IILSA as a one stop service provider agency in local government have a legal basic there are Permendagri number 24/2006, Permendagri Number 57/2007, Regulation of Mayor Pasuruan City Number $08 / 2010$ and regulation of Mayor pasuruan city Number 06/2013.

b. Communication: it can be seen from coordination between IILSA of pasuruan city with related local government offices (SKPD). coordination is done well during this run in accordance with the duties, but with the technical coordination with other agencies, suggests that IILSA of Pasuruan city can not do the licensing service completely.

c. Resources there is staff's ability to implement one stop service. employee's ability to do one-stop service obtained from the trainings that have been done, then discipline of staff can be reached because reward system of punishment and facilities are also available to meet the standard for an organization's duties are held one stop service.

d. Bureaucratic structures that are in accordance with local regulations of Pasuruan city.

e. The Target group from the Implementation of one stop service there are the society that need a service of Bussines License.

2. The Investment and Integrated Licensing service Agency (IILSA) of pasuruan City can perform the service well based on the defined rules. However, IILSA of Pasuruan city can not be said to be capable of implemented integrated services due to coordination with the technical departments are still required. so does that still require a recommendation from the applicant's technical department before applying for License in IILSA. This showed that the integration of services that are did by IILSA can not be said to be successful because of the system and also the authority factor. authority to examine the technical field problem not owned by IILSA Pasuruan which only acts as an agent of service providers only.

\section{Recommendation}

In order to address the development of technology and excellent service demands, IILSA of Pasuruan city should be make a improvement to implement services in a way provide mobile service to the community ("pick up a ball" service), or also applying online system without requiring the applicant to come to the office. Considering with the current technological developments are increasing and demand the public service providers to provide convenience to the community in providing services, including in IILSA of Pasuruan City. And then, about inhibiting factor about internet network, to anticipate the disruption that the Internet will eventually unified the administration of licensing services, IILSA should have a technician in the IT expert so that when there is interference or trouble on a computer network it can be solved quickly.

\section{ACKNOWLEDGMENTS}

Thanks to My Parent for all support and all what they gave to me and to my supervisor commite, Dr. Siti Rochmah, M.Si and Dr. Ratih Nur Pratiwi, M.Si, that already given the time, suggestions, opinions, also had guided the supported this research.

\section{REFERENCES}

[1]. Ratminto \& Atik Septi Winarsih. (2005) Manajemen Pelayanan Pengembangan Model Konseptual, Penerapan Citizen's Charter dan Standar Pelayanan Minimal. Yogyakarta, Pustaka Pelajar

[2]. Sugiyono. (2010) Memahami Penelitian Kualitatif. Bandung, Alfabeta.

[3]. Arikunto, Suharsini. (2006) Prosedur Penelitian Suatu Pendekatan Praktek. Jakarta, Rineka Cipta.

[4]. Berman, P. (1980) "Thinking about Programmed and Adaptive Implementation: Matching Strategies to Situation", in Why Policies Succed or Fail. Edited by Ingram and Mann, 1980. London, Sage Publication.

[5]. Bogason, Peter. (2001) Public Policy and Local Governance. Institution in Post Modern Society. Cheltenham, Sage Publication. 
[6]. BPS Kota Pasuruan. (2012) Kota Pasuruan Dalam Angka. Pasuruan, Badan Pusat Statistik.

[7].Hardiyansyah. (2011) Kualitas Pelayanan Publik Konsep, Dimensi, Indikator, dan Implementasinya. Yogyakarta, Penerbit Gavamedia.

[8]. Hasibuan, Malayu. (2002) Manajemen Sumber Daya Manusia. Jakarta, Gunung Agung.

[9]. Hill, Michael. (1993) Policy Process: A Reader. London, University of Newcastle.

[10]. Hogwood, B.W and L.A. Gunn. (1984) Policy Analysis for The Real World. London, Oxford University Press.

[11]. Ibrahim, Amin. (2008) Pokok-pokok Administrasi Publik \& Implementasinya. Bandung, PT. Refika Aditama.

[12]. Iskandar. (2009) Metodologi Penelitian Kualitatif. Jakarta, GP Press.

[13]. Islamy, M. Irfan. (2001) Policy Analysis. Seri Monografi Kebijakan Publik. Malang, Program Pascasarjana Universitas Brawijaya.

[14]. ------------. (2002) Strategi Peningkatan Pelayanan Publik di Era Otonomi Daerah. Malang: Makalah yang disajikan pada seminar "Good Governance" Ilmu Administrasi Publik.

[15]. ------------, (2003) Dasar-dasar Administrasi Publik dan Manajemen Publik. Malang, Program Studi Ilmu Administrasi UNIBRAW.

[16]. ---------------, (2007) Prinsip-Prinsip Perumusan Kebijaksanaan Negara. Cetakan Ke-14. Jakarta, Bumi Aksara.

[17]. Mursamita, Tirta Nugra, dkk. (2010) Reformasi Pelayanan Publik dan Pembangunan Daerah. [Internet]. Available research from: $<$ www.transparansi.or.id.PDf $>$ [Accessed March, 02, 2013].

[18]. Nugroho, Riant. (2011) Public Policy. Edisi Ketiga. Jakarta, PT. Elex Media Kompetindo.

[19]. Nurcholis, Hanif. (2007) Teori dan Praktik Pemerintahan dan Otoda. Edisi Revisi. Jakarta, PT. Grasindo.

[20]. Pasolong, Harbani. (2008) Teori Administrasi Publik. Bandung, Penerbit Alfabeta.

[21]. Peraturan Menteri Dalam Negeri Nomor 24 Tahun 2006 tentang Pedoman Penyelenggaraan Pelayanan Terpadu Satu Pintu.
[22]. Rahmayanty, Nina. (2010) Manajemen Pelayanan Prima. Yogyakarta, Graha Ilmu.

[23]. Sholichin, Abdul Wahab. (2008) Analisis Kebijaksanaan: Dari Formulasi kemampuan Implementasi Kebijaksanaan Negara, Cetakan Keenam, Edisi Kedua. Jakarta, Bumi Aksara.

[24]. Suryono, Agus. (2002) Jurnal Administrasi Negara Vol I no 2 tentang Manajemen Pelayanan Publik. Malang, FIA UNIBRAW.

[25]. Suryono, Agus. (2011) Manajemen sumber Daya Manusia: Etika dan Standar Profesional Sektor Publik. Malang, Universitas Brawijaya Press (UB-Press).

[26]. Tjiptoherijanto, Prijono \& Mandala Manurung. (2010) Paradigma Administrasi Publik dan Perkembangannya. Jakarta, Penerbit Universitas Indonesia (UI-Press).

[27]. Wahyuni, Diyan. (2009) Kualitas Pelayanan Pembuatan Surat Izin Usaha Perdagangan (SIUP) di Dinas Perindustrian Perdagangan dan Koperasi Kota Cilegon. [Internet]. Available from <http://fisipol.unsul.ac.id > [Accessed March, 10, 2013].

[28]. Wibawa, Fahmi. (2007) Panduan Praktis Perizinan Usaha Terpadu. Jakarta, PT Grasindo.

[29]. Wibowo, Agung. (2013) Pakar: Birokrat Kerap Persulit Izin Usaha Demi Fulus. [Internet]. Available from: $<$ http://www.metrotvnews.com > [Accessed March, 02, 2013].

[30]. Yuwono, Sony, dkk. (2008) Memahami $A P B D$ dan Permasalahannya: Panduan Pengelolaan Keuangan Daerah. Malang, Bayumedia.

[31]. Zauhar, Susilo. (2007) Reformasi Administrasi: Konsep, Dimensi, Strategi. Jakarta, PT Bumi Aksara. 